\title{
NATURAL AND CULTURAL HERITAGE PRACTICES IN \\ TRIGLAV NATIONAL PARK
}

TATIANA BAJUK SENČAR

The following paper contains a discussion of the theoretical and methodological challenges to understanding the complex reality of heritage production and preservation practices within Triglav National Park (TNP), focusing in particular on the relationship between natural and cultural heritage. As Slovenia's only national park, TNP is a central site of Slovenia's national heritage as well as a unique landscape that itself is home to a whole range of heritage elements, both natural and cultural. The central challenge to understanding the culture of heritage within the park lies in the heritage diversity within the park. The author assesses the extent to which employing the concept of contiguity and mapping out fields of contiguity in which diversity is expressed and practiced can enable the researcher to analyze the way that the relationship between nature and culture, between natural and cultural heritage has been defined, expressed and realized in diverse ways over time.

Keywords: Triglav National Park, anthropology of heritage, nature, culture, contiguity, heritage naturalization.
$V$ pričujočem besedilu avtorica razpravlja o teoretskih in metolodoških izzivih pri razumevanju kompleksnosti procesov produkcije in ohranjanja dedišcine v Triglavskem narodnem parku (TNP), v katerem je poudarjeno predvsem razmerje med naravo in kulturo oz. naravno in kulturno dedišcino. Kot edini slovenski narodni parkje TNP središcni kraj nacionalne dedišcine, predstavlja pa tudi enkratno pokrajino šstevilnimi naravnimi in kulturnimi elementi dedišcine. Osrednji izziv pri razumevanju dediščine v parku je v njeni raznovrstnosti. Avtorica premišlja, do katere mere labko uporaba koncepta kontigvitete, kakor ga je postavil Maxwell, in mapiranje polj kontigvitete, v katerih se raznovrsnost izraža in prakticira, omogočata analizirati, kako se na različne načine in skoz čas opredeli, izraža in udejani razmerje med naravo in kulturo oz. med naravno in kulturno dedišcino.

Ključne besede: Triglavski narodni park, antropologija dedišcine, narava, kultura, kontigviteta, naturalizacija dedišcine.

The following paper will contain a discussion of the theoretical and methodological challenges to shedding light on the complex reality of heritage production and preservation practices within Triglav National Park (TNP), focusing in particular on the relationship between natural and cultural heritage. It is based on ongoing research being currently conducted within the context of the research project entitled Triglav National Park: Heritage, Actors, Questions and Solutions. The study is being carried out by an inter-institutional team of anthropologists and ethnologists coordinated through the Institute of Slovenian Ethnology at the Scientific Research Centre of the Slovenian Academy of Sciences and Arts.

As Slovenia's only national park, TNP is a central site of Slovenia's national heritage as well as a unique landscape that itself is home to a whole range of heritage sites, both natural and cultural. Thus it is not surprising that the central challenge to understanding the reality of heritage within the park lies in understanding heritage diversity within the park. Diversity in this context refers to the diverse forms of heritage in the park, the range of social actors that play varied roles in everyday heritage practices as well as the multiple claims to heritage and authority that existing heritage actors employ to further particular heritage agendas and practices. 


\section{DIVERSITY AND CONTIGUITY}

This focus on diversity also extends to researching diverse understandings of natural and cultural heritage within the boundaries of TNP. Our approach to cultural and natural heritage - and consequently to nature and culture - are presumed not to be neutral categories but socio-cultural constructions with which existing heritage actors involved in everyday life within Triglav National Park create a relationship with the heritage in the park. Just as Bender (1998) argued in the case of Stonehenge "there is never a landscape, always many landscapes", research of TNP heritage practices is based on the assumption of the existence of not only different kinds of heritage elements (ie natural elements vs cultural elements) but also diverse constructions of these presumably different heritage formations. Anthropological and ethnological research into the practices of heritage across cultures has demonstrated that the relation between nature and culture, natural and cultural heritage in the realm of practice is anything but straightforward. In some heritage research studies such as that of Breglia's (2006) ethnography of heritage practices in Chichen Itza, the diversity of understandings of nature and culture extended to diverse heritage actors not even agreeing on whether certain landscape formations were elements of natural or cultural heritage.

In preliminary fieldwork, the relationship between natural and cultural heritage emerged as a potential, yet not predetermined site of contention. However, automatic presumption of contestation and opposition following from the fact of diversity can stem from essentialist understandings of culture in which all social actors adhere to a single set of values and codes of conduct - and diversity can automatically become an inherent source of conflict. Instead, this research is based on the understanding that culture is diverse and not based primarily on similarity. Maxwell's understanding of contiguity in culture is useful in this regard. Contiguity was first put forth as an element of community solidarity by philosopher David Hume and means being adjacent to or conterminous in time and space. Maxwell extends the concept of contiguity to operate as a basis for cultural solidarity, and it does not simply refer to fact that social actors can share the same space at the same time but that the interaction and social relationship between such cultural actors enables the development of community. "Contiguity-based solidarity ... derives from the ways in which people interact, and thereby come to know and care about one another" (Maxwell 2012: 54). The sense of identification with a culture thus does not necessarily derive from a set of similarities - adherence of a particular set of values and codes but is lodged primarily in the sphere of practice, a history of association and contact. Difference no longer automatically subverses community solidarity and presumes opposition. These varied social actors and their concomitant compilation of heritage practices form the culture of heritage within the park.

Introducing an analytical understanding of culture as inherently diverse and based on contiguity does not imply overlooking or diminishing the existence of tensions, contention and conflicts - it implies not equating diversity with them. Basing one's research of heritage practices in TNP on a notion of culture based on contiguity does however provide a framework 
for analysis that can incorporate the fact of diversity in a constructive manner. In addition, a notion of culture based on diversity and contiguity also foregrounds interaction among social actors and practices as the processes through which culture is imagined, developed, enacted and maintained. Thus the main ethnographic goals in researching the culture of heritage focus primarily on carefully documenting the diversity of cultural actors, tracing out the multiple fields of contiguity in which actors interact, and identifying the mechanisms and strategies they employ to enact this diversity in practice as well as the end result of these practices.

\section{TRIGLAV NATIONAL PARK: HISTORY AND LOCATION}

TNP is Slovenia's only national park and is situated in the northwestern past of the country. The land encompassed by the park forms part of the southeastern section of the Alps that extends along Slovenia's border with Italy as well as Austria. The park is named after Triglav, Slovenia's highest mountain situated in the heart of the park. Triglav is in its own right an element of national heritage and in this capacity is featured on the national coat of arms and the flag. The park in its present form covers approximately 84.000 hectares. Ideas for the park in that particular area had circulated for years before the park was founded, with the first concrete proposal for the park have been made public in 1906. Plans of the park finally came to fruition in 1924 with the creation of the Alpine Conservation Park. At that time, the park totalled approximately 1600 hectares and primarily covered what is referred to as the Triglav Lakes Valley that immediately surrounds Triglav. TNP grew steadily in size: a decree passed in 1961 resulted in an increase of the park to 2000 hectares and the Law on Triglav National Park, passed in 1981, extended the park to include the valleys and villages that surround the Triglav Lakes Valley. TNP now includes 25 settlements, and its territory extends across 9 different municipalities: Bovec, Bohinj, Kranjska Gora, Bled, Tolmin, Kobarid, Gorje, and Jesenice. According to official sources, approximately 2300 persons live inside the boundaries of the park. TNP can be further broken down into two sectors: the central area, which measures approximately 55.000 hectares, and the peripheral area, which totals approximately 29.000 hectares. The main difference between the two areas is linked primarily to the sort of development that is allowed in these different regions.

\section{HERITAGIZATION PROCESSES IN TRIGLAV NATIONAL PARK}

Shedding light on existing diverse understandings of nature and culture does not only encompass a documentation of all existing understandings of natural and cultural heritage and the spokespersons for such understandings but also the ways in which these understandings emerge and interact in varied spheres of practice related to the park. In effect we could argue that the development of an understanding of natural or cultural heritage is a normative 
act in and of itself, as it concerns defining a particular, often ideal sort of relationship with a heritage element or heritage landscape. This process, often referred to as heritagization (Hewison 1987; Walsh 1992), implies establishing a relationship with a particular purpose as well as a set of rights and responsibilities. The heritagization of TNP has a particular history, and the first calls for a park within the vicinity of Triglav also coincide with the first nature conservation efforts in Slovenia (Spomenica 1920). While one can in effect determine a beginning of the TNP heritagization process and even identify the first handful of actors who took on this role, the diversity of actors, agendas and understandings of natural and cultural heritage within the park multiplied over time.

\section{TRIGLAV NATIONAL PARK AND THE DISAGGREGATED STATE}

Begining at the formal level, one can say that the park is a legal and social construction whose existence and operation is based in great part on the Law of Triglav National Park, the first version having been passed in 1981 and the second in 2010. These laws defined the extent and nature of the park and also provide the groundwork for a special administrative body, the TNP Public Institution, which is accorded the responsibility of managing the park and its diverse sites of heritage. One can argue that a legally and socially powerful heritage construct is written into the jurisdictions and responsibilities of the TNP Public Institution, and for this reason it can be considered a central actor - albeit an institutional one - in the TNP heritage landscape.

The TNP Public Institution articulates its understanding of natural and cultural heritage as well as its institutional mission statement on its own website:

The primary aim is the protection of nature, conservation of outstanding nature and culture, protection of endemic, rare and threatened plant species, natural ecosystems and elements of inanimate nature, as well as the conservation and maintenance of the cultural landscape. (http://www.tnp. si/get_to_know/C177/)

In addition to conserving the park's natural and cultural landscapes, the TNP Public Institution is entrusted with ensuring coordinated, sustainable development of the area to the benefit of park inhabitants:

\section{The Triglav National Park strives to ensure coordinated, sustainable development of the area and industries practiced in the park, in particular agriculture, forestry and tourism, and to provide sustainable material and other conditions for the life and work of the local population. (ibid.)}

According to the TNP Public Institution website, proper management ensures the coordination of these two major goals - heritage conservation and development:

The missions of TNP is to provide professional implementation support to decisions on nature protection and development and to open up possiblities 
for the coordination of different interests and activities in the protected area. Proper management ensures implementation of the park's objectives and sets an example of management conducted for other areas. (ibid.)

One could argue that the TNP Public Institution is the central state authority and representative in the park. However, upon further research one realizes that approaching the state as a monolithic entity and presuming a uniform approach from the state does not allow one to capture the range of actors who speak in the name of the state. Working from a more disaggregated notion of the state (Slaughter 2005) - as an entity comprised of numerous sets of government networks - provides an analytical framework for capturing the diversity of state constructions of and approaches to natural and cultural heritage as well as the role of the state in "managing" said heritage.

A quick look at the members of the council of the TNP Public Institution provides evidence of the range of government bodies who speak in the name of the state, from the Ministry of Agriculture and Environment, the Ministry of Culture, to the Institute for Nature Conservation and the National Institute for the Protection of Cultural Heritage. There are numerous state spokespersons both for natural and cultural heritage. In addition, the TNP Public Institution is not the only national government body that has the authority to operate within the protected areas of TNP, and not all of these government bodies are dedicated primarily to heritage conservation, while their operation does not a priori conflict with it (municipal Agricultural Counseling/Advisory Service, Institute for Nature Conservation, etc.). We must also factor in the nine municipalities that are also present in the park who represent the interests of the park inhabitants, interests that they also represent in the council of the TNP Public Institution.

In addition, the Law on Triglav National Park is of course not the only law that governs everyday life in the park as well as the government bodies that operate within it. Given our focus on nature and culture, it is also pertinent to mention those laws dealing with the management of natural and cultural heritage, including the legislation defining the management of forests, agriculture, the delimitation of hunting and fishing, laws on nature conservation, on the preservation of cultural heritage, zoning legislation, and water management laws. As we have learned from preliminary interviews with chosen state representatives, all these laws must be harmonized with each other, and the new Law on Triglav National Park went through a meticulous harmonization process with representatives from different state ministries and institutes. Each institution has its particular jurisdiction, priorities and history concerning understandings of natural and cultural heritage. Preliminary interviews also suggest that the new approach to park management ushered in by the new law in effect strives towards a more disaggregated system of jurisdiction for the state - that no one state body is meant to make all decisions regarding TNP operations.

It is also important to recognize that the majority of the aforementioned government agencies, including the TNP Public Institution, are also international heritage actors through, at the most basic level, a number of international conventions that Slovenia has 
signed concerning nature and culture conservation. In addition, national parks such as TNP are also incorporated into international networks of heritage conservation - be they predominately natural or cultural. One can map out the positioning of the TNP Public Institution within existing global heritage networks - including IUCN (International Union for the Conservation of Nature), ALPAC (Alpine Network of Protected Areas), the EUROPARC Federation of European protected areas, WCPA (World Commission of Protected Areas), and UNESCO, among others. TNP Public Institution employees are quite active in participating in networks of this kind. We can take as an example the institution's director, Mr. Martin Šolar, whose studies and activities on the international level comprise a significant aspect of his activities. He completed a master's degree in the conservation of natural heritage in Zagreb in 2002, and has dedicated a fair amount of time during the course of his 18 year career at the TNP Public Institution to international networking. Currently he is president of the intergovernmental committee UNESCO MaB (Man and Biosphere) and a member of the commission for protected areas at the IUCN - one of the key organizations for nature conservation. He was also a member of the council of the EUROPARC federation - a federation uniting the protected areas of Europe - for six years.

\section{NON-STATE HERITAGE ACTORS}

The government heritage actors that we have outlined demonstrate the extent to which Slaughter's thesis of the disaggregated state composed of diverse government networks seems to best capture the inherently diverse and multifaceted role of the state in TNP heritage practices. It is also important to track the implications of this disaggregation on constructions of natural and cultural heritage - how many normative heritage visions does the disaggregated state espouse, and how are they linked to one another?

However, the state comprises only one (albeit disaggregated) actor on the heritage scene. One very important and rather heterogeneous group includes the park's inhabitants. The park's gradual expansion from the mountainous regions around Triglav to the surrounding valleys resulted in the inclusion of a significant amount of arable land and villages in TNP. The park thus is now home to a number of park inhabitants, who are in fact owners of the land on which they live. The state is thus not the only landowner in the park.

Park inhabitants as a group can be broken down further in accordance to profession: farmer (organic and non-organic), tourism service providers, restaurant/tavern owners, business owners, amateur collectors. Park inhabitants in general and in their respective subgroups have their particular relationships to heritage within the park and as such invoke a certain claim to heritage and speak with particular constructions of authority in relationship to heritage - be they persons who practice a certain form of heritage (alpine dairy farmers, cheese manufacturers, owners of tourist farms), who promote or capitalize on heritage (tourism service providers and local tourist organizations) or who collect and display heritage (amateur collectors). 
There are also groups of heritage actors that may include park inhabitants but that also encompass actors beyond the boundaries of the park: tourist actors and conservation actors. Tourist actors active within TNP are not necessarily locally positioned but are active within the park and in heritage practices, particularly those of promotion of TNP as a national park. These include individual tourism service providers, businesses, as well as regional and national tourism associations - recently this also includes foreign tourism service providers whose tours of Slovenia also include regions within the boundaries of the park.

Conservation actors include individuals, conservation groups and NGOs in Slovenia dedicated to conservation issues in general as well as conservation and national heritage issues in relation to TNP in particular. In recent years, these heritage actors played an active role in the discussions and legal preparations that led to the drafting of the new Law on Triglav National Park passed in 2010. ${ }^{1}$ In addition, this new law also provides conservation actors with a formal role in heritage management in the park, as conservation groups and NGOs in accordance with the new TNP legislation have been accorded a member of the Council of the TNP Public Institution. Conservation groups with their view of TNP as predominately an element of national heritage contribute yet another perspective on the aims and responsibilities inherent in managing TNP as a national park and, consequently, on natural and cultural heritage.

\section{FIELDS OF CONTIGUITY FOR NATURAL AND CULTURAL HERITAGE}

David Lowenthal's essay on natural and cultural heritage is very useful in this regard as he discusses similarities and differences specific to natural and cultural heritage. While some of his arguments do not necessarily correspond to the situation in TNP, the factors that he employs to gauge the relationship between natural and cultural heritage are analytically speaking very useful. They include, among others, the particular development of natural or cultural heritage; the role of nationalism in heritage; the differentiation between heritage elements and the everyday; the use of history in the construction of heritage; the different bases for people's identification with heritage; the role of economic motivation in heritage conservation; the nature of leaders, spokesmen, and crusaders for heritage; the arguments and motives for heritage conservation; the role of authenticity in defining heritage, attitudes towards replacement and extinction, the role of human interference in heritage management (Lowenthal 2005).

The key contribution of Lowenthal's essay is that it focuses in depth on the relationship between natural and cultural landscape in a way that does not presuppose an opposition between one and the other but instead is an extensive comparison of both forms of heritage that unfolds on the basis of a discussion of all the factors outlined above. Employing a

1 I have analyzed in part the role of national conservation actors in debates concerning the future of the park in my work on tourism and development within the park (Bajuk Senčar 2005). 
number of different criteria also enables Lowenthal to meticulously explore both similarities and differences both in the nature and practices of natural and cultural heritage. While the systematic discussion of practices is extremely enlightening, the discussions that make generalizations on the nature of natural and cultural heritage do not necessarily correspond with practices across cultures and run the risk of essentialization.

Instead we find that it is very useful to employ Lowenthal's approach as a point of departure with the caveat of focusing primarily on the definition of fields of contiguity among existing heritage actors and the range of activities, strategies and practices that they employ in striving to further their research agenda. By field of contiguity we are referring to the field of social practice or action defined by diverse interaction heritage actors. Such fields of practice are not necessarily bound by the physical boundaries of the park itself, as it is not necessary that interactions that are meaningful for the construction of heritage in the park unfold between social actors that are face-to-face.

One of the potential factors to aid one in defining and classifying varied fields of contiguity in such a complex case as that of Triglav National Park is that of scale. A number of heritage researchers have focused on the interplay between different scales as constitutive of dynamics of interaction between constructions of natural and cultural heritage that heritage actors invoke in the case of specific heritage sites. Interactions can be plotted within, along or across different levels - the local, regional, national, and international. Even expanding a field of contiguity to include additional levels of heritage practices will enable researchers to to track the relation between understandings of natural and cultural heritage in the case of a particular site and make apparent certain heritage strategies that are otherwise elided. Researchers have portrayed the different ways that the interplay between different levels of heritage practices affects the relationship between constructions of natural and cultural heritage. ${ }^{2}$

At the majority of heritage sites, heritage actors are active at numerous levels, and it is only when accounting for all of them can one trace out the dimensions of the arena in which crucial heritage interactions unfold for nature and culture. For example, in many cases this means the interplay between lower and higher levels of heritage practice. Tiima Peil (2005) relates how in Estonia the introduction of global or international heritage standards have affected the way that the particular specificities of the Pakri Peninsula are defined. According to Peil, many heritage sites in Estonia have had to deal with the issue of reconciling diverse legacies existent in heritage sites into a single, national conceptualization of heritage defined as Estonian. Heritage sites thus become sites of negotiation with "unwanted" or "irreconcilable" elements of history and space, negotiations that are also cast in terms of nature and culture. In the case of Pakri Peninsula, Peil documents the strategy of "naturalizing" a heritage landscape - meaning emphasizing the natural features of a particular landscape to the detriment of others - as a means of dealing with, or, more

2 In the following discussion of the broadening fields of contiguity we will focus primarily on a set of essays written for a special issue of the the International Journal of Heritage Studies dedicated exclusively to the relationship between natural and cultural heritage. 
precisely, glossing over those aspects of a site defined as problematic - in this case, aspects linked to Estonia's Soviet heritage. In this case, the "naturalization" of heritage is also justified by those actors as a means of abiding with international heritage standards, and thus naturalization in this case, which it was by some actors intended to de-problematize a particular heritage site, also results in the site's homogenization or standardization.

Both Germundsson (2005) and Setten (2005) identify another strategy that is similar to that of naturalization that they both term aestheticization. In this case, a heritage landscape is equated with its appearance - its aesthetics - in such a way that the appearance of natural landmarks is prioritized over all else. In addition, in both cases this occurs as a heritage strategy apparent from the interaction between regional (or local) and national heritage actors. Germundsson points out the hegemonic effect of aestheticization in the case of Scania in Sweden, where aestheticization operates as an ideological tool to elide local or regional heritage landscapes into a single national heritage narrative that is composed of stereotypical landscapes. This strategy - which also erases the processes of landscape production - is particularly apparent in the case of Scania, whose landscape visually does not fit into existing national stereotypes. Gunhild Setten's analysis of farmlands in Norway brings up another issue linked to aestheticization. Setten documents the aestheticization of agricultural farmlands as a direct product of their heritagization at the national level as these farmlands are fit into a particular aspect of national identity linked to rural heritage. The aestheticization is linked to a particular relationship with the landscape that is reduced to a gaze, a relationship that does not at all coincide with that of the farmers of the area, whose engagement with the landscape is based on cultivation of the land. The aestheticization of the landscape elides the cultivation of the land and the experience of locals into a visualization of the distant observer. The cultural heritage of the farmlands is subsumed into a particular, albeit national vision of rural heritage.

When expanding one's field of contiguity or field of analysis to include actors from multiple levels of heritage action, it seems from the essays sketched out above that certain strategies inherent to natural heritage point to a pattern - that cultural heritage is more locally defined and often subsumed into constructions of natural heritage that are relatively speaking more broadly defined - either at the regional or the national level - and more hegemonic in nature. However, such generalizations are not accurate, and the danger lies in naturalizing certain heritage strategies by casting them as natural (and self-evident) while others are cultural.

Werner Krauss' (2005) analysis of the debates concerning the nomination of Wadden Sea as a UNESCO world heritage site depicts a different dynamic between constructions of natural and cultural heritage. It also provides an interesting case of naturalization strategies that have not been able to maintain a semblance of self-evidence. In addition, Krauss' analysis of the conflict between conservationists who have proposed the nomination and the locals who vehemently oppose it demonstrates that practices akin to naturalization are also employed by proponents of cultural heritage. Conservationists wished to protect Wadden 
Sea, its unique natural landscape and cultural monuments from the effects of additional human activity through a UNESCO nomination. However, the locals who did not agree with this project took quite an active role in denouncing the role of conservationists supporting the nomination as overly invested stakeholders using scientific discourse to turn Wadden Sea into their laboratory (Krauss 2005:42). In addition, the locals forwarded their local identity as Friesians - which Krauss cast as an essentialist cultural identity - and their authority as local stakeholders to counteract the power of the scientific discourse employed by conservationists and their naturalizing of the Wadden Sea landscape.

Researchers thus cannot maintain a static understanding of the relationship between nature and culture, between natural and cultural heritage if they take into account the significance of the practices, strategies and interactions between relevant actors even across numerous levels. In addition, natural and cultural heritage are not only defined through interaction and practice in numerous fields of action but also develop and evolve over time. Bosse Sundin (2005) in an analysis of natural heritage in Sweden identifies and tracks two discourses of natural heritage in Sweden - the antiquarian and the environmentalist - and how the interaction between the two over time affected understandings of nature and culture. Sweden's efforts at conserving its natural heritage were cast first in the discourse of antiquarianism, which is often identified with cultural heritage and the conservation of individual cultural heritage sites, monuments or objects. However, given the fact that Sweden's early forms of nationalism were cast in natural terms - the history of Sweden is linked with glaciation of the land - Sundin argues that the land, natural landmarks and natural sites were also accorded national importance in terms of an antiquarian discourse (Sundin 2005: 11). However, the onset of environmental discourse brought with it a shift in the way that natural heritage was imagined, namely from a set of individual sites and objects to an environment to be protected from the threats of pollution and waste of resources. Sundin argues that while at the beginning of the 20th century, antiquarian discourse was hegemonic and influenced the way that conservationist viewed nature, by the 1960s environmentalism was on the rise, supplanting antiquarian discourse as the dominant mode of thinking about heritage. This in turn resulted in a shift obviously in the understanding of nature conservation but also of cultural heritage conservation, which also became focused less on ancient monuments to cultural environments or landscapes (Sundin 2005:15).

It is important to realize the extent to which natural and cultural heritage are social relationships and social constructs; they evolve, develop, and change. They are processes produced, maintained, modified and subverted by heritage actors. While it is analytically useful to map out and delegate actors and discourses to particular levels - be they local, regional, national, global - the fields of contiguity in which these actors interact can become quite fluid. Heritage actors as well as heritage preservation discourses - particularly if they are global in nature - travel quite effectively and cannot in practice be presumed to be the domain of a particular actor or set of actors. For example, local inhabitants in TNP can 
and have invoked global heritage discourses and conservation criteria to counter particular development projects espoused by other (national) park actors (Bajuk Senčar 2005). National nature conservation actors in discussions with local representatives may borrow discursive categories from development and identity discourses to promote heritage management policies in the park. Mapping out fields of contiguity is to be considered a first step, a proper framing of heritage processes, the essence of which takes place in the sphere of interaction among diverse actors, interactions often coded as contestation. It is only in mapping out not only the range but the course of practices as contiguity, as a series of interactions within a field of practice, that a more accurate depiction of the culture of heritage may emerge.

\section{REFERENCES}

Bajuk Senčar, Tatiana

2005 Kultura turizma. Antropološki pogledi na razvoj Bohinja. Ljubljana: ZRC SAZU.

Bender, Barbara

1998 Stonehenge: Making Space. Oxford and New York: Berg.

Breglia, Lisa

2006 Monumental Ambivalence: The Politics of Heritage. Austin: University of Texas Press.

Germundsson, Tomas

2005 Regional Cultural Heritage versus National Heritage in Scania's Disputed National Landscape. International Journal of Heritage Studies 11 (1): 21-37.

Hewison, Robert

1987 The Heritage Industry: Britain in a Climate of Decline. London: Metuen.

Krauss, Werner

2005 The Natural and Cultural Landscape of Northern Friesland. International Journal of Heritage Research 11 (1): 39-52.

Lowenthal, David

2005 Natural and Cultural Heritage. International Journal of Heritage Studies 11 (1): 81-92.

Maxwell, Joseph Alex

2012 A Realist Approach to Qualitative Research. London: Sage.

Peil, Tiina

2005 Estonian Heritage Connections - People, Past and Place: The Pakri Peninsula. International Journal of Heritage Studies 11 (1): 53-65.

Setten, Gunhild

2005 Farming the Heritage: On the Production and Construction of a Personal and Practised Landscape Heritage. International Journal of Heritage Studies 11 (1): 67-79.

Slaughter, Anne Marie

2005 A New World Order. Princeton: Princeton University Press.

Spomenica

1920 Spomenica Odseka za varstvo prirode in prirodnih spomenikov. Glasnik Muzejskega društva za Slovenijo 1(1-4): 69-75.

Sundin, Bosse

2005 Nature as Heritage: The Swedish Case. The International Journal of Heritage Studies 11 (1): 9-20. 
Triglav National Park website

(http://www.tnp.si)

Walsh, Kevin

1992 The Representation of the Past: Museums and Heritage in the Postmodern World. London: Routledge.

\section{PRAKSE NARAVNE KULTURNE DEDIŠČINE V TRIGLAVSKEM NARODNEM PARKU}

$V$ pričujočem besedilu avtorica razpravlja o teoretskih in metolodoških izzivih pri osvetlitvi kompleksnosti procesov produkcije in ohranjanja dedišcine $v$ Triglavskem narodnem parku (TNP), v katerem je poudarjeno predvsem razmerje med naravo in kulturo oz. med naravno in kulturno dedišcino.

Kot edini slovenski narodni park je TNP središcni kraj nacionalne dedišcine, predstavlja pa tudi enkratno pokrajino šstevilnimi naravnimi in kulturnimi elementi dediščine. Osrednji izziv pri razumevanju dedišcine v parku je $v$ njeni raznoterosti. $V$ tem kontekstu se raznovrstnost ne nanaša samo na elemente dediščine v parku, temveč tudi na niz družbenih in institucionalnih akterjev, ki imajo različne vloge v vsakdanjih dedišcinskih praksah, utemeljenih na stevilnih prisvajanjih dedišcine; ta pa se sklicujejo na različne oblike avtoritete, da labko uresničijo svoje vizije v zvezi s dediščino.

Avtorica trdi, da različna pojmovanja naravne in kulturne dedišcine sama po sebi ne vodijo neogibno h konfliktom in nasprotovanju, kar je $v$ nasprotju $z$ domnevo, ki morebiti izvira iz esencialističnega razumevanja kulture. Tako pristop, izbran za pričujočo razpravo, temelji na razumevanju kulturne dediščine kot raznotere po svoji naravi in zasnovane na načelu kontigvitete, kakor jo je razvil Maxwell (2012). Avtorica si prizadeva za analitično zemljevidenje polj kontigvitete, s katerim lahko raziskovalec sledi različnim načinom, kako družbeni akterji določajo svoj odnos do naravne in kulturne dedišcine - to je proces dedišcinjenja - in različnim mehanizmom, ki jih uporabljajo za vzdrževanje svojih podob o dediš̌ini. To v naslednjem koraku tudi omogoča analizo različnih načinov, skaterimi je opredeljena dihotomija narava-kultura, in raznovrstnih načinov sklicevanja dediščinskih akterjev nanjo. Po avtoričinem mnenju je na ta način mogoče analizirati, kako se na različne načine in skoz čas opredeli, izraža in udejani razmerje med naravo in kulturo oz. med naravno in kulturno dedišcino.

Dr. Tatiana Bajuk Senčar, research fellow, ZRC SAZU Institute of Slovenian Ethnology, Novi trg 2, SI-1000 Ljubljana, Slovenia, tatiana.bajuk@zrc-sazu.si 